\author{
Yıldıray YILDIRIM \\ Dr. Öğr. Üyesi| Assist. Prof. Dr. \\ Bayburt Üniversitesi, İnsan ve Toplum Bilimleri Fakültesi Tarih Bölümü, Bayburt-TÜRKIYYE \\ Bayburt University, Faculty of Humanities and Public, Department of History, Bayburt-TURKEY \\ ORCID: 0000-0002-7175-3700 \\ yildirayyildirimad@hotmail.com
}

\title{
Kaymakam Mehmed Hüsnü Bey’in Raporuna Göre 19. Yüzyll Sonunda Bayburt Kazasının Genel Durumu
}

$\ddot{\mathbf{O} z}$

Osmanlı Devleti'nde 1864 Vilayet Nizamnamesi, idari yapılanmayı yeniden düzenlemişti. Bu düzenleme ile kazalara yönetici olarak kaymakamlar atanmaya başlandı. Kaymakamlar atandıkları yerlerin kalkınması ve merkezde oluşturulan yeni kurumların buralarda da tesisi için çaba sarf etmekteydi. Bu kişilerden biri de Bayburt Kaymakamı Mehmed Hüsnü Bey'di. Ocak 1897 tarihinde Bayburt'a atatan Mehmed Hüsnü Bey, Rumi 1315 yılında Anadolu Vilayetleri Umum Müfettişliğine Bayburt kazasının 1314 (1898-1899) yılına dair genel durumunu ortaya koyan bir istatistik hazırladı. İstatistik; mülkiye, maliye, nafia, maarif, adliye, muhabere ve belediyeye ait bilgiler içermekteydi. Mehmed Hüsnü Bey'in hazırlamış olduğu istatistik temelinde oluşturulan bu çalışmada, XIX. yüzyılın sonunda kazanın idari yapılanması ve kurumları, kaza nüfusu ile bunun niteliği, maliyeye ait gelir-gider durumu, tarım ve hayvancılık ile mülk satışları, başta Ziraat Bankası olmak üzere nafıanın mali durumu, kazada mevcut modern eğitim kurumları ve belediyenin durumu değerlendirilmeye çalışıldı. İstatistikteki bilgileri desteklemek ve bazı konuları detaylandırmak amacıyla, döneme ait salnamelerden de önemli ölçüde faydalanıldı. Böylelikle bu çalışma, Bayburt kazasının XIX yüzyıl sonlarındaki genel durumunu ortaya koymayı amaçlamaktadır.

Anahtar Kelimeler: Bayburt Kazası, Mehmed Hüsnü Bey, Bayburt Kazası İstatistiği.

\section{General Situation of Bayburt City at the end of $19^{\text {th }}$ Century According to Mehmed Hüsnü Bey's Report}

\begin{abstract}
In the Ottoman Empire, the 1864 provincial regulations reorganized the administrative structure. With this arrangement, district governors began to be appointed as administrators to city. The district governers made efforts to develop the places they were appointed and to establish new institutions in there. One of them was the Governor of Bayburt Mehmed Hüsnü Bey. Mehmed Hüsnü Bey, who was appointed to Bayburt at January 1987, prepared a statistic report about the general situation of Bayburt city for 1314 (1898-1899) in 1315 Rumi. This report included some information about administrative, finance, public works, education, juidiciary, communications and municipilaty. In this study, which was established within the framework of this statistics, administrative structure and institutions of the city at the end of the 19th century, city population and its quality, income-expenditure status of the finance, agriculture-livestock and property sales, the financial status of public works (particularly Ziraat Bank), modern educational institutions in the city and the situation of the municipality were evaluated. In addition, annuals of the period were also used significantly in order to support the information in the statistics and to detail some issues. The aim of this study was to reveal the general situation of the Bayburt city at the end of the 19th century.
\end{abstract}

Keywords: Bayburt City, Mehmed Hüsnü Bey, Bayburt City Statistic. 


\section{Giriş}

Osmanlı Devleti'nde, 19. yüzyılda her alanda köklü değişism ve dönüşümler gerçekleşti. Özellikle yüzyılın ikinci yarısında hızlanan değişimler doğal olarak Bayburt kazasını da etkilemekteydi. Devlet bu değişimlere mümkün olduğu kadarıyla önem vermekte ve kazalara atanan yöneticiler de ellerinden geldiğince yeni kurumların tesisi için çaba sarf etmekteydi. Devletin yeni kurumlara verdiği önem özellikle eğitim kurumlarında kendini açık bir şekilde göstermekteydi. Örneğin aşağıda yer alan o dönemdeki modern eğitim kurumlarının yanında geleneksel tarzda eğitim veren kurumlar da mevcut ise bunlar kendi hâllerine bırakılmıştı ve eğitim kurumlarından bahseden kayıtlarda genellikle sadece modern eğitim kurumlarından bahsedilmekteydi. Bölgelere atanan yöneticiler de bu kurumların tesisi için mesai harcamakta ve görev bölgelerinin kalkınmasına çabalamaktaydı. Bu görevlilerden biri de 1 Kasım 1898 tarihinde maarif gelirlerinin arttırılması konusunda gösterdiği gayretlerden dolayı liyakat madalyası verilen ve Ocak 1897-Temmuz 1899 tarihleri arasında yaklaşık iki buçuk yıl boyunca Bayburt Kaymakamlığını yapan Mehmed Hüsnü Bey’di (MF.MKT. 421/15; A.MKT.MHM. 680/29; BEO 1346/100917).

Mehmed Hüsnü Bey, Rumi 29 Mart 1315 (M. 10 Nisan 1899) tarihinde Anadolu Vilayetleri Umum Müfettişliğine ${ }^{1}$ Bayburt'un Rumi 1314 (13 Mart 1898-12 Mart 1899)² senesine ait idarî işlemlerine dair bir istatistik hazırlamıştı. Tek varak şeklinde hazırlanmasına rağmen oldukça uzun bir metin olan bu istatistiğin en üst kısmında tablo halinde mülkiyeye, maliyeye, adliyeye, nafiaya, maarife, belediyeye ve haberleşmeye dair rakamsal verilere yer verilmiş ve ardından metin kısmında bu konulardaki her başlık için detaylara değinilmiştir. Fakat istatistikte daha ziyade mülki ve mali konular hakkında ayrıntı mevcut iken özellikle adli konularda rakamsal veriler dışında hiçbir bilgi mevcut değildir. Bu durum idarecilerin idari ve mali işlere diğer alanlara nazaran daha büyük önem verdiklerinden kaynaklandığı kanaatini oluşturmaktadır. Bu nedenle istatistikteki

\footnotetext{
${ }^{1}$ Umum Müfettişlikleri 93 Harbi sonrasında II. Abdülhamid zamanında ortaya çıkmıştı. Berlin Kongresinde Doğu Anadolu'daki altı vilayette islahat yapılması hususunda yapılan dış baskılar neticesinde bölgeye bir teftiş heyeti gönderilmiş ve bu heyetle birlikte Ahmet Şakir Paşa Umumi Müfettiş olarak görevlendirilmişti. Oluşturulan Umumi Müfettişlikler ile Osmanlı Devleti, sorunlu bölgelerde neler olup bittiğini anlamaya ve iktidarını buralarda güçlendirmeye çalışmıştır. Bu konuda detaylı bilgi için bakınız: Cemil Koçak, Umumi Müfettişlikler, İstanbul: İletişim Yayınları, 2010; Selçuk Akşin Somel, "Osman Nuri Paşa'nın 17 Temmuz 1885 Tarihli Hicaz Raporu” A.Ü., D.T.C.F., Tarih Araşttrmaları Dergisi, 18(29), 1995, 43-65; Ayfer Genç Yılmaz, "Devlet Kapasitesi ve Umumi Müfettişlikler Altyapısal İktidarın Yerelde İnşası", Siyasal Bilimler Dergisi, 1(1), 2013, 43-65; Engin Çağdaş Bulut, "Devletin Taşradaki Eli: Umumi Müfettişlikler", CTAD, 11(21), 2015, 83-110.

${ }^{2}$ Rumi 1314 yılı, miladi 1898-1899 yılını kapsadığından çalışmada sürekli iki tarih vermek yerine istatistik için verilen tarihlere mahsus olmak üzere Rumi tarihin verilmesi uygun görülmüştür.
} 
konular, mümkün mertebe kazaya ait salnamelerden desteklenmeye çalışılmıştır. Ancak istatistik 1314 yılına ait olmakla birlikte 1313-1314 değil 1315 y1lına ait olan salnamedeki veriler kullanılmıştır. Çünkü istatistik ile örtüşen bilgilerin bu yıla ait sayıda bulunmaktadır. Örneğin 1313-1314 yılına ait salnamede Kaymakam Vekili Cemil Bey iken, tashih ve ilave kısmında Mehmed Hüsnü Bey'in olduğu bilgisi mevcuttu. 1315 yılına ait salnamede ise Mehmed Hüsnü Bey Temmuz ayında Osmaniye'ye mutasarrıf olarak atandığı hâlde (Rumi takvime göre yılın sadece ilk üç ayı görevde kalmıştı.) kaymakam olarak o kaydedilmiştir.

\section{Mülkiye}

Bayburt kazası, 1314 senesinde idarî olarak Merkez, Pulur, Hart (Aydıntepe) ve Everek nahiyeleri olmak üzere dört kısımdan oluşmaktaydı. ${ }^{3}$ Bayburt kazası, kaza idare meclisi tarafından idare olunmaktaydı. Bu meclis; idari, mali ve adli işlerde yöneticilere yardımcı olmak ve gerekli kararları alıp onları uygulamaya sokmakla görevli bir kurumdu. Kazanın en üst idarecisi olan kaymakam aynı zamanda idare meclisinin de başıydı. Kaymakamın başkanlığında naip, müftü, mal müdürü ve tahrirat kâtibi meclisin tabi üyelerini oluşturmaktaydı. Bunların yanında halkın seçtiği ikişer Müslüman ve Gayrimüslim üyeler, meclisi oluşturmaktaydı (Ortaylı 2011: 82-83). Bu esaslara göre Kaymakam Mehmed Hüsnü Bey’in başkanlığında Bayburt Kazası İdare Meclisi, tabi üyeler Naip: Halil Fahri Efendi, Müftü: Ali Rıza Efendi, Mâl Müdürü İsmail Hakkı Efendi ve Tahrirat Kâtibi Mehmed Vamık Efendi ile seçilmiş üyeler: Maşuk Efendi, İbrahim Efendi, Siyon Efendi ve Bani Ağa'dan oluşmaktaydı (SVE R.1315: 185).

İstatistiğin ait olduğu 1314 senesinde İdare Meclisi tarafından 1.052 evrak görüşülüp tartışılmış, 1.480 arz, mektup ve tezkere yazılmış, 532 telgraf çekilmişti. Meclise 1.058 emir, mektup, tezkere vesaire havale edilmişti. Meclise gelen emir, mektup ve telgrafın sayısı da toplam 2.313'ten oluşmaktaydı. Ayrıca İdare Meclisi o yıl, Kop Dağı'nda bulunan jandarma karakolunun kısmen yıkılmış olması nedeniyle burayı tamir ettirmeye çalışmaktaydı. Ancak inşaat mevsiminin geçmesinden ötürü tamirat bitirilememişti (Y.EE., 133/1).

Osmanlı idari teşkilatlanmasını köklü bir şekilde düzenleyen 1864 Tuna Vilayet Nizamnamesinde nahiyelerden bahsedilmekle birlikte bunların kuruluşu, organları ve yönetiminin nasıl olacağı konusunda herhangi bir bilgi yer almamaktaydı. Nahiyeler hakkındaki asıl düzenleme onu taşra yönetiminin bir kademesi haline getiren 1871 İdare-

\footnotetext{
${ }^{3}$ Mehmed Hüsnü Bey'in istatistiği 29 Zilkade 1316 tarihlidir. Ancak arşivde belge tarihi yanlışlıkla 1310 olarak kaydedilmiştir. Y.EE. 133/1.
} 
i Umumiye-i Vilayet Nizamnamesi ile gerçekleşti (Ortaylı 2011: 99). 1871 Nizamnamesinin 54. Maddesine göre her nahiyeye bir nahiye müdürü atanacak ve burada nahiye meclisi (hey’et-i müşâvere) bulunacaktı (Seyitdanlığlu 2010: 83). Fakat meclislerin istenildiği gibi görev yapamaması yabancı müdahalesine neden oldu ve 6 Nisan 1876'da yeni bir nizamname hazırlandı. Bu çerçevede vali tarafından atanan nahiye müdürünün başkanlığında toplanacak olan nahiye meclislerinin üye seçimlerinde, dinî ve etnik grupların belirli oranda temsil edilmesi kararlaştırıldı (Çadırcı 1997: 253).

Bayburt'un üç nahiyesinde de nüfus çoğunluğunun Müslüman olması dolayısıyla nahiyelerin durumunu düzenleyen hükümler çerçevesinde nahiye müdürü ile meclis azaları Müslümanlardan, müdür muavinlikleri ise gayr-i Müslimlerden seçilmişti. Ayrıca buralara bir de nahiye kâtipleri atanmıştı (Y.EE., 133/1).

Bayburt'a bağlı nahiyelerin, nizamname doğrultusunda ancak istatistiğin hazırlandığı Rumi 1314 senesinde teşkilatlandığı anlaşılmaktadır. Rumi 1313 yılına ait salnamede Bayburt'ta 14 nahiye mevcut iken (SVE R. 1313: 196) bir sonraki salnamede raporda olduğu gibi 3 nahiye mevcuttu. Buradaki bilgilere göre nahiyelerin yönetici kadroları şöyleydi.

Pulur Nahiyesi: Müdür: İskender Beğ, Muavin: Yorgi Ağa Nahiye Kâtibi: Emin Efendi, azalar: Abdullah Efendi, Diğer Abdullah Efendi, Münhal (boş).

Hart Nahiyesi: Müdür: Abdülhamid Ağa, Muavin: Ohannes Ağa, Nahiye Kâtibi: Münhal, azalar: İsmail Efendi, Arslan Beğ, Münhal.

Everek Nahiyesi: Müdür: Hasan Efendi, Muavin: Miran? Efendi, Nahiye Kâtibi: Mevlüd Efendi, azalar: Esad Ağa, Diğer Esad Ağa, Ahmed Efendi (SVE R.1315: 187188).

Nahiyeler, bu tarihte teşkilatlanmasına rağmen kadroların tam olarak teşekkül etmediği, Pulur'da bir aza, Hart'ta ise bir aza ile nahiye kâtibinin eksikliğinden anlaşılmaktaydı. Nahiyelerin teşekkülüyle buralarda Mekâtib-i İbtidâiye-i İslâmiye açılmış ve bu okullara öğretmenler tayin edilmişti. Bu okullardan aşağıda maarif k1sminda bahsedilecektir.

Nahiyelerde hükümet işlerinin sağlıklı bir şekilde yürütülmesini sağlamak amacıyla birer adet süvari tahsildarı ile asayişi sağlamak için jandarma istihdam edilmişti. Fakat nahiye polisleri için gerekli paranın tahsis edilememesinden dolayı bu kurum oluşturulamamıştı. Nahiyelerdeki hükümet konaklarının inşasının da onaylanan planlar çerçevesinde inşaat mevsiminin başında yapılması kararlaştırılmıştı. Bu iş için tespit 
edilen masraflar da yardım yoluyla varlıklı ve vatansever kişilerden tahsil edilmekteydi (Y.EE., 133/1).

Kazada bir adet Posta ve Telgraf Merkezi bulunmaktayd. Burada, Merkez Müdürü: Hüseyin Efendi, Muhabere Memuru Rüşdi Efendi, Mûsil-i Muharrerât Ahmed Ağa ile çavuşân olarak da Rüşdi Ağa, Mehmed Ağa, İsmail Ağa, diğer Mehmed Ağa, Mustafa Ağa ve Abdullah Ağa görev yapmaktaydı (SVE R.1315: 146; Y.EE., 133/1). Y11 içerisinde bu kurum tarafından yapılan işlemlerde kazaya toplam 1.775 mektup ile 538 telgraf gelirken, kazadan toplam 1.480 mektup ile 532 telgraf gönderilmişti. Dolayısıyla bir yıl içinde bu kurumda toplam 4.325 işlem yapılmıştı (Y.EE., 133/1).

Nüfusla ilgili işlemlerin yapıldığı nüfus dairesi, nüfus memuru olarak 250 kuruş maaşlı Mehmed Torak Efendi ve 125 kuruş maaşlı bir de kâtip tarafından idare edilmekteydi. Dairenin 1314 yılı zarfindaki hasılatı 15.641 kuruştan ibaret olup, önceki seneye nispetle 4.023 kuruş artış gerçekleşmiş̧ti (SVE R.1315: 186; Y.EE., 133/1).

Raporun başında "Mülkiye" başlığı altında Bayburt'un nüfusu hakkında temel bilgiler verilmiş, daha sonra metin kısmında detaylara girilmişti.

Tablo 1. Bayburt'un Rumi 1314 yılı nüfusu

\begin{tabular}{|c|c|c|c|c|}
\hline \multirow{5}{*}{ Nüfûs-1 Mevcûde } & \multirow{5}{*}{$\begin{array}{l}\text { Teba'a-i Devlet-i } \\
\text { 'Aliyye }\end{array}$} & \multirow{2}{*}{ Müslim } & Zükûr & 25.096 \\
\hline & & & İnâs & 21.422 \\
\hline & & \multirow{2}{*}{ Gayr-i Müslim } & Zükûr & 5.648 \\
\hline & & & İnâs & 5129 \\
\hline & & \multicolumn{2}{|c|}{ TOPLAM } & $\mathbf{5 7 . 2 9 5}$ \\
\hline \multirow{4}{*}{ Tevellüdât } & \multirow{2}{*}{\multicolumn{2}{|c|}{ Müslim }} & Zükûr & 730 \\
\hline & & & İnâs & 432 \\
\hline & \multirow{2}{*}{\multicolumn{2}{|c|}{ Gayr-i Müslim }} & Zükûr & 624 \\
\hline & & & İnâs & 137 \\
\hline \multirow{2}{*}{ Münâkehât } & \multicolumn{2}{|l|}{ Müslime 'Â'id } & Aded & 397 \\
\hline & \multicolumn{2}{|l|}{ Gayr-i Müslime 'Â'id } & 'Aded & 15 \\
\hline \multirow{4}{*}{ Vefeyât } & \multirow{2}{*}{\multicolumn{2}{|c|}{ Müslim }} & Zükûr & 292 \\
\hline & & & İnâs & 263 \\
\hline & \multirow{2}{*}{\multicolumn{2}{|c|}{ Gayr-i Müslim }} & Zükûr & 529 \\
\hline & & & İnâs & 90 \\
\hline
\end{tabular}

Kazanın 1314 senesi başındaki toplam nüfusu 56.545 kişiyken, y1l içerisinde 1.880 kişi doğmuş, 1.474 kişi ise vefat etmiş ve 43 kişi de dışarıdan gelip kazaya yerleşmişti. Böylece 1315 yılının başında kaza nüfusu 57.295 kişiye ulaşmıştı. Nüfusun dini gruplara göre dağılımına bakıldığında Müslümanların sayısı 46.518, gayr-i Müslimlerin ise 10.777 kişiden oluşmaktaydı. Gayr-i Müslimlerden 740'1 Rum geriye kalanı ise Ermeni’ydi. Bayburt kaza merkezi 1.667'si Müslümanlara, 319'u Ermenilere 
ve 17'si Rumlara ait olmak üzere 2.003 hane ve 16 mahalleden oluşmaktaydı (Y.EE., 133/1). Bu mahallelerden 12'sinde sadece Müslümanlar, 3 'ünde sadece gayr-i Müslimler ve 1'inde de gruplar birlikte yaşamaktaydı. ${ }^{4}$ Tüm bu mahallelerde 6.859'u Müslüman 973'ü Ermeni ve 100'ü Rum olmak üzere 8.932 nüfus mevcuttu. Kazanın sahip olduğu 171 adet köyden 1'i 200, 11'i ise 100 haneden fazla olup, 9'u 75-100, 29'u 50-75, 61'i 25-50, 60’1 ise 5-25 arasında haneye sahipti. Bu köylerde 39.659'u Müslüman, 9.704'ü gayr-i Müslim olmak üzere 49.363 kişi yani toplam nüfusun \%86,2'si yaşamaktaydı (Y.EE., 133/1). Raporda köylerdeki toplam hane sayıs1 verilmemekle birlikte 1315 y1lına ait salnamede merkezle birlikte 171 köyde 9.151 hane olduğu bilgisi mevcuttu. Böylece köylerdeki hane sayısının 7.148 olduğu anlaşılmaktadır (SVE R.1315: 191).

Grupların oranlarına bakıldığında toplam nüfusun \%81,2'sini Müslümanlar oluşturmaktayken, gayr-i Müslimlerin oranı $\% 18,8$ 'di. Bu veriler kazada Müslümanların gayr-i Müslimlerden 4 kat fazla nüfusa sahip olduğunu ortaya koymaktadır. Cinsiyete göre grupların nüfus ve toplam nüfusa oranları ise şöyleydi: Müslüman erkekler 25.096 $\% 43,8$, kadınlar 21.422 \%37,4; gayr-i Müslim erkekler 5.648 \%9,9, kadınlar 5.129 $\% 8,9$ 'du. Cinsiyet oranlarına bakıldığında Müslümanlarda daha fazla olmakla birlikte her iki grupta da erkek nüfusun çoğunlukta olduğu anlaşılmaktadır.

Kazada 1314 yılı içerisinde, Müslümanlar tarafından 397, gayr-i Müslimler tarafından da 15 evlilik gerçekleşmişti. Müslümanlardan 292 erkek, 263 kadın, gayr-i Müslimlerden 529 erkek 90 kadın olmak üzere 1.174 kişi hayatını kaybetmişti. Bu da toplam nüfusa oranla \%2'ydi. Aynı yıl gerçekleşen doğumlarda ise Müslümanların 730 erkek, 432 kız (1.162); gayr-i Müslimlerin 624 erkek, 137 k1z (761) olmak üzere toplam 1.923 çocuk dünyaya gelmişti (Y.EE., 133/1). Toplam nüfusta olduğu gibi burada da erkeklerin oranı kızlara nispetle bir hayli fazlaydı. Ayrıca doğum oranlarında dikkati çeken bir husus da iki grup arasındaki doğum oranıdır. Doğumların grupların toplam nüfusuna oranı Müslümanlarda \%2,5 iken gayri-Müslimlerde \%7,1'di. Bu veriler 1314 yılında kazada oransal olarak gayr-i Müslimlerin da fazla çocuk sahibi olduğunu göstermektedir. Dışarıdan yerleşenler hariç ölüm ve doğumlar karşılaştırıldığında kaza nüfusu 749 artmış ve nüfus artış oranı \%1,3 olarak gerçekleşmişti.

Osmanlı ailesi üzerine yapılan çalışmalarda sanılanın aksine çok çocuklu ailelerin fazla olmadığı ve genellikle anne babayla birlikte hane başına düşen fert sayısının 5 'i dahi

\footnotetext{
${ }^{4}$ 19. yüzyılda gerek mahalleler gerekse köylerde yaşayan gruplar hakkında detaylı bilgi için bakınız: Yunus Özger, XIX. Yüzyll Bayburt (Sosyo-Ekonomik, İdari ve Demografik Yapı), İstanbul: IQ Kültür Sanat Yayınc1lı, 2008, s.179-193, 214-285
} 
bulmadığ1 ortaya konmuştur (Tabakoğlu 2003: 152; Demirel, Gürbüz ve Tuş 1992: 101118). Bayburt kazasındaki durumu da hane sayılarıyla nüfusun karşılaştırması ortaya koymaktadır. Bu karşılaştırma neticesinde anlaşılmaktadır ki Bayburt merkezde hane başına düşen fert sayısı ortalaması Müslümanlarda 4,1, Ermenilerde 3,1 ve Rumlarda da 5,9 olmak üzere genel ortalama 4,5, köylerde ise 6,9' du. Tüm kazanın ortalaması ise 6,3'tü. Bu veriler, yaşam koşullarının doğal sonucu olarak kaza merkezinde çekirdek, köylerde ise geniş aile tipinin daha yaygın olduğuna işaret etmektedir.

Raporda nüfusun niteliği hakkında da ayrıntılı bilgilere yer verilmektedir. $\mathrm{Bu}$ bilgilere göre, toplam nüfus içerisinde Müslüman erkek nüfusunu oluşturan 24.658 kişiden 1.409'u askerlik çağındaydı. Bunlardan 714'ü muayenesiz olmaları nedeniyle ortada (taburda) bırakılmıştı ki bunlar içerisinde askerlikten kaçan ve yakalanarak zorla askere alınan 13 kişi de bulunmaktaydı. Geriye kalan 695 kişiden ise 312'si 1. tertip, 82'si 2. tertip olarak ayrılmıştı. İçlerinden askerliğini tamamlayan 200 kişi de redif sınıfına nakledilmişti. Geriye kalanlardan 9'u maluliyetinden dolayı askerlikten muaf tutulmuş, 51'inin senelik izinleri sona ermiş, 3'ünün muamelesi yenilenmiş, 27'si vefat etmiş, 5 'inin askerlik yaşının altında olduğu tespit edilmiş ve yakalananlar dışında askerlikten kaçan 6 kişi de bulunamamıştı.

Müslim ve gayr-i Müslim olmak üzere toplam 30.211 kişiden ibaret erkek nüfustan 15.142'si 20-60 yaş aralığında bulunmaktaydı. Bu kişiler içinde kamu görevlisi olanlardan 163'ü sakat veya hasta, 171'i mektep hocas1, mahalle imamı ve medrese öğrencisi, 15'i rahip, 1.954'ü asker ve jandarmaydı. Bu kişiler çıkarıldığında kazada askerlikle mükellef olanların sayısı 12.843'tü. Bunların da 1.923'ü bedel karşılığında geriye kalanı ise şahsen askerlikle yükümlü olduğu kayıt altına alınmıştı (Y.EE., 133/1).

\section{Maliye}

İstatistikte kazada 1314 yılında mali işlemlerden sorumlu olan idareciler ile aldıkları maaşlar detaylı olarak verilmiştir. Buna göre tapu işlemlerinden sorumlu Tapu Kâtibi Tevfik Efendi'nin bahsedilen yıl zarfındaki toplam maaşı 1.729 kuruş 30 pareden (aylık 145 kuruş) ibaretti. Maliye işlemlerini idare eden Mâl Müdürü İsmail Hakkı Efendi'nin maaşı 720, Tahrir Vergi Memuru (muavin) Şükrü Efendi’nin 500, refiki Mazhar Efendi'nin, 300, Sandık Emini Hurşid Efendi'nin 360 kuruştu. Bunların dişında 120 kuruş maaşlı dört süvari, 170 kuruş maaşlı iki piyade tahsildarı ile dörder ağnam memuru ve bir geçici kâtip ile dokuz bekçi, mali işlerle ilgili kurumlarda görev yapmaktaydı. Bunlara 1314 yılında aylık maktu olarak 5.132,5 kuruş ücret ödenmişti. Bu dönemde ağnam baş memuru istihdam olunmadığı gibi aşar ihale işlemleri kaymakam 
tarafından yerine getirilmiş ve bu işlemlerden kendisi ayrıca ücret almamıştı. Orman idaresinde görevli memur Ahmed Bey 400 kuruş ve 200'er kuruş maaşlı iki piyade kolcusu bulunmaktaydı. Bahsedilen yıl zarfında Orman idaresinin gelirleri 7.963 kuruş, masrafları ise 5.800 kuruştu. Gelir-giderler karşılaştırıldığında yıllık gelirin giderden 2,163 kuruş fazla olduğu anlaşılmaktadır (SVE R.1315: 186; Y.EE., 133/1).

İstatistiğin başında mülkiyede olduğu gibi maliyeye ait gelir-giderler hakkında da temel bilgiler verilmiş ve metin kısmında bunların ayrıntısına yer değinilmiştir. Bu bilgiler şöyledir:

Tablo 2. Maliyeye dair Rumi 1314 yılı verileri.

\begin{tabular}{|l|c|}
\hline \multicolumn{1}{|c|}{ Gelir-Gider Türü } & Miktar (Kuruş) \\
\hline Emlâk ve 'Akâr Virgüsü & 401.035 \\
\hline Temettu'Virgüsü & 44.470 \\
\hline Bedel-i 'öşrî̀ & 206.678 \\
\hline Â'şâr & 1.314 .805 \\
\hline Âğnâm & 324.972 \\
\hline Rüsûm-1 Mütenevvi'a ve Hâsılât-1 Müteferrika & 194.609 \\
\hline Yekûn Vâridât & $\mathbf{2 . 4 8 6 . 6 6 8}$ \\
\hline Mesârif-i Dâ'ir & 1.200 .000 \\
\hline Sînin-i Sâbıka Bakâyâsından Tahsîlât & 692.637 \\
\hline 1314 Senesi Emvâl-i 'umûmiyesinden Tahsîlât & 2.204 .196 \\
\hline 1314 Senesi Bakâyâsı & 282.472 \\
\hline
\end{tabular}

Bir önceki seneye kıyasla emlak ve akar vergisinde 60 , temettü vergisinde 12.815 kuruş olmak üzere toplam 12.877 kuruş azalma gerçekleşmişti. Bedel-i öşride 3.202, aşarda 220.164, ağnam vergisinde 10.684, çeşitli belediye ile müşterek vergilerde 7.375 , mahkeme ve nüfus hasılatında 8.152 kuruş olmak üzere bu kısımlarda ise toplamda 245.575 kuruş gelir fazlası oluşmuştu (Y.EE., 133/1).

Genel gelirlerden zamanında tahsil edilemeyen (bakâya kalan) 282.472 kuruştan, askerlik bedeline dâhil olan 184.038 kuruşun tahsili daha sonraya bırakılmıştı. 57.800 kuruş aşardan sahiplerinin ibraz ettiği depozito akçesinden tahsil edileceği ve 28.530 kuruş mâl sandığında hak sahiplerinin aşardan zimmeti olduğundan bunlar hesaba aktarılmış ve zamanında tahsil edilemeyen gerçek miktar 12.104 kuruş olarak gerçekleşmişti. Bu tutar kamuya ait mallara kıyasla \%0,5 nispetinde bile değildi. Buna karş1lık 692.637 kuruş önceki seneye ait bakayadan ve 150.000 kuruş da askeri kurumlar için yardım tahsil edilmişti (Y.EE., 133/1). 
Yukarıda bahsedilen 12.104 kuruş bakayanın 11.474 kuruşu, 1895 yılında bölgede meydana gelen Ermeni ayaklanmalarına karışmayan Ermenilerin ${ }^{5}$ askerlik bedeli olup yoksulluklarından dolayı kendilerine mühlet verilmesini talep etmeleri sonucunda 1315 senesine bırakılmıştı. Ancak emlâk, akar ve temettü vergileriyle ağnam vesaire vergi kısımlarından olan para bakaya devredilmeyip kanuni süresi zarfında tahsil edilmişti. 1313 ve 1314 senelerine ait toplam gelirlerden ertelenen askerlik bedelleri hariç 1315 senesine devredilen bakaya, depozito akçesi, kontratçı zimmeti gibi kısaca tüm kısımlar 110.000 kuruş civarındaydı. Ayrıca 1312 senesi sonuna kadar kime ait olduğu bilinmeyen mallardan bu iki sene zarfında 1.249.149 kuruş tahsilat gerçekleşmiş ve 500.000 kuruş askeri kurumlara yardım toplanmıştı (Y.EE., 133/1).

Tarım ve Hayvancılık: Bayburt kazasının kuzey sınırını deniz seviyesinden 1.650 (1.875) metre yüksekliğinde olan Vauk (Vavuk) Dağı, Güney sınırını ise 2.200 (2.409) metre yükseklikte olan Kop Dağı oluşturmaktaydı. ${ }^{6}$ Kazadan geçen Trabzon-Erzurum anayolu güzergâhı Trabzon tarafına Vauk Dağı, Erzurum tarafına ise Kop Dağı ile bağlanmaktaydı. Bu iki dağın arası 15 saat $(80 \mathrm{~km})$ olup uzantıları kazayı adeta kuşatmaktaydi.

Bayburt, Sünür ve Hart adlarında 1300-1400 metre yüksekliğinde verimli ovaları ile benzeri düzlüklerden oluşan bir havzaydı. Bu ovalar ve düzlükler küçük yollarla birbirlerinden ayırmakta ve buralarda ziraat ve çiftçilik yapılmaktaydı. Arazinin önemli bir kısmını sulayan birçok akarsu mevcuttu. Ovanın ve uzantılarının öbür tarafında olan Sürmene, Of, Rize, Gümüşhane ve buralara bağlı arazilerin dağlık ve taşlık olmasından dolayı buraların ziraata kabiliyeti yoktu. Bu nedenle Bayburt kazasının geniş arazisi ve Kop Dağı ile başlayan Erzurum ve Tercan ve benzeri ovaları uzun süreden beri Bayburt Kasabasının hububat alış-verişinde çok önemli bir değişim merkezi olmasına olanak vermiş ve bu nedenle Bayburd'un Bay Yurd'dan ${ }^{7}$ ortaya çıkmış olduğu fikri doğmuştu.

\footnotetext{
${ }^{5}$ Bu konuda detaylı bilgi için bakınız: Yunus Özger, 1895 Bayburt Ermeni Ayaklanmaları, İstanbul: IQ Kültür Sanat Yayınc1lık, 2007.

${ }^{6}$ Raporda rakımlar 1.650 ve 2.200 olarak verilmişse de günümüzdeki ölçümler sonucunda bu iki geçidin tabelalarında 1.875 ve 2.409 metre yazmaktadır.

${ }^{7} \mathrm{Bu}$ tahminin çıkış noktası Evliya Çelebi'nin eseri olmalıdır. Evliya Çeleb'nin eserinde Bayburt isminin menşei şöyle anlatılmaktadır: "Evsâf-ı kal'a-i kadîm-i Bayburd - Âl-i 'Osmân'ın ecdâd-1 i'zâmıyla beraber Mâhân diyârından gelen Ak Koyûnlular bu şehrde tavattun itmişlerdir. Yaylağa çıkûb gezinirken Gümüşhâne ovalarından kenz-i 'azîm dimek olan ma'adenleri bulûb bay oldıklarıçün bu şehre de (Bay Yurt) dimişler, sonra tahrîf idilerek (Bayburd) denmişdir.” Ayrıca raporda yer alan bu bilgiler aşağı yukarı aynı şekilde salnamelerde de geçmektedir. Aslında Bayburt şehrinin adı ve buranın ne zaman kurulduğu hakkında kesin bilgi olmamakla birlikte, henüz daha Türklerin buraya gelmesinden önce Ortaçağ Ermeni kaynaklarında şehir için "Payberd" denildiği bilinmektedir. Evliya Çelebi, Evliya Çelebi Seyahatnamesi, İstanbul: İkdam Matbaas1, H.1314 [M. 1896-97], s.344; Salnâme-i Vilâyet-i Erzurum, Defa 14, s.294;
} 
Bayburt, 1314 yılında sekiz on kazanın hububat ambarı konumundaydı. Mevsimlerin şiddetli tesirine ve ulaşımda meydana gelen aksaklıklara rağmen 10-15 sene öncesine kadar Trabzon'a sürekli hububat ihracatı yapılmakta iken son senelerde ancak üç dört senede bir defa birkaç yüz bin kile hububat sevk edilebilmekte ve bazen buradaki iskeleyle dışarıya ihraç olunabilmekteydi. Hububatın ihracata dâhil olan kısmından elde edilen öşür gelirleri birkaç bin liraya yaklaşmaktaydı. Fakat son yıllardaki bu azalma mahallî şartları iyiden iyiye zarara uğratmaktaydı.

Raporda kazada üretilen tarım ürünleri hakkında detaylı bilgi verilmekle birlikte ölçü birimi olarak şinik kullanıldığından bu konuya kısaca değinmekte fayda vardır. Osmanlı Devletinde hububat ölçeği olarak kullanılan kile, 1841 y1lına kadar bölgeden bölgeye değişirken, bu tarihten itibaren 1 kile her yerde yaklaşık 37 litre olarak tespit edilmişti. Bu da 20 okkalık eski buğday ağırlığına eşitti ki bir okka 1,282 kg. olduğundan 1 kile 25,64 kilograma karş1lık gelmekteydi (Hinz 1990: 51; Pakalın 2004: 281,723). İlk başta 1 kile $=4$ şinik $=8$ kutu=16 zarf=37 litre şeklinde ayarlanmışken, 24 Eylül 1881 tarihli kararnâme ile 1 yeni kile=10 yeni şinik=100 ölçek=1000 yeni kutu=10000 zarf şeklinde kabul edilmişti. Böylece Osmanlı Devletinin son döneminde 10 şinik 1 kileye yani 37 litre=25,64 kilograma karşılık gelmekteydi (Kallek 24.01.2019). Aşağıdaki tabloda Bayburt'ta üretilen ürünlerin kilogramı bu hesaba göre verilmiştir.

Tablo 3. 1314 senesinde Bayburt’ta yoğun olarak yetiştirilen ürünler

\begin{tabular}{|l|l|l|}
\hline \multicolumn{1}{|c|}{ Ürün Cinsi } & \multicolumn{1}{c|}{ Miktar } & \multicolumn{1}{c|}{ Miktar (Kg.) } \\
\hline Buğday & 1.448 .676 (Şinik) & 3.714 .405 \\
\hline Sarıbaş Buğday & 701.734 (Şinik) & 1.799 .245 \\
\hline Çavdar & 180.857 (Şinik) & 463.717 \\
\hline Arpa & 1.801 .515 (Şinik) & 4.619 .084 \\
\hline Patates & 540.000 (Kıyye/Okka) & 692.280 \\
\hline Sogan & 1.500 .000 (Kiyye/Okka) & 1.923 .000 \\
\hline Çeşitli ot & 21.987 .784 (Kiyye/Okka) & 28.188 .339 \\
\hline
\end{tabular}

Tablodan anlaşılacağı üzere kazada insanlar için en temel besin ürünlerinden buğday ve sarıbaş buğdaydan 5.513.650, patates ve soğandan 2.615.280 ve hayvan yemi olarak da arpa ve ottan ise 32.807.423 kilogram ürün elde edilmişti. Bu veriler yukarıdaki ürünlerin kazada ciddi miktarda üretildiğini ve tarımın temelini oluşturduğunu ortaya koymaktadır. Raporda miktar verilmeden Hububat dişında fiğg, keten tohumu, mercimek, karaburçak, mısır(darı), kavun, karpuz yetişmekte olduğu bilgisi mevcut ise de bunların üretiminin oldukça az olmasından miktar verilmemiştir (Y.EE., 133/1). Ayrıca bu

İsmet Miroğlu, "Bayburt", TDV İslâm Ansiklopedisi, https://islamansiklopedisi.org.tr/bayburt (23.01.2019) 
tarihlerde yukarıdaki ürünler dışında zeyrek, fasulye, elma, armut, erik, şalgam, lahana, pancar, havuç, çiriş, lazut, yer elması ve benzeri ürünler de yetiştirilmekteydi (SVE R.1315: 192).

Kazada tarımla birlikte şüphesiz hayvancılık en önemli ekonomik faaliyetti. $\mathrm{Bu}$ tarihte kazada irili ufaklı bakar (sığır, öküz, inek, manda) cinsinden 45.573, ganem (koyun-keçi) cinsinden 123.211 ve feres (at, beygir) cinsinden 2.120 adet beslenmekteydi. Raporda feres cinsinin nesli tükenecek derecede, ganem ve bakar cinslerinin ise ufak ve az faydalı olduğu ifade edilmektedir (Y.EE., 133/1). O tarihte Bayburt'un 9.151 hane olduğu düşünülürse hane başına yaklaşı 5 büyükbaş, 13,5 küçükbaş düşmekteydi. Bu miktar aslında günümüz şartlarında oldukça iyi bir rakam gibi görülse de toplumun 5'te 4'ünün tarım ve hayvancılıkla uğraştı̆̆ 1 bir dönemde yetersiz görüldüğ̈̈ istatistikte vurgulanmaktadır.

Mehmed Hüsnü Bey, istatistikte tarımın daha iyi yapılabilmesi için alınması gereken tedbirlere de yer vermektedir. Ona göre tarımsal kalkınma için yatılı ve uygulamalı bir ziraat mekteb-i ibtidâiye açılmalıydı. Bununla beraber nakliye vasıtalarında at, deve ve kağnı arabasına olan bağl1lıktan kurtulmalı ve bunların yerine tekerlekli arabalara geçilmeliydi. Ziraatta kullanılan alet ve edevatın yeni tarzda olması ve 1slahhanenin tesisi gerekmekteydi. Bu konuda zamanla tedbirler almak üzere şimdilik her takımı dörder saban, ikişer tapan, birer zirai tohum, çayır ve orak makinelerini içermek şartıyla bu bölgenin arazisine elverişli beş takım modern alet ve edevat gönderilmeliydi. Bu takımlar, ilk başta sermayesi 2 milyon kuruşu aşan Bayburt Ziraat Bank Şubesince ödenerek büyük arazi sahibi çiftçilere ortalama bir ücret karşılığında dağıtılmalıydı. Yeni aletlerin gösterdiği fayda, son derece ilkel olan mevcut edevatın terkine hizmet edecekti. Bu konuda gerçekleşecek ilerlemenin Bayburt ile ticarî ilişkisi olan diğer kazaları da etkileyeceği aşikârdı. Bu gerekçelerle Mehmed Hüsnü Bey, yatılı ve uygulamalı ziraat mekteb-i ibtidâiye ile sslahhanenin açılması için müsaade buyurulmasını istemekteydi (Y.EE., 133/1). Mehmed Hüsnü Bey'in ifadelerinden anlaşılacağı üzere bu tarihlerde kazada tarım ve hayvancılık konusunda geri kalınmaktayd1. Özger, bu alanlardaki gerilemenin en önemli nedeni olarak 1893 ve 1894'de bölgede meydana gelen kuraklık ile 1895 yılında Bayburt merkez ve köylerinde çıkan Ermeni olaylarının üretim faaliyetleri üzerindeki olumsuz etkisini göstermektedir (Özger 2008: 469).

Mülk Satışları: Bayburt'ta 1314 yılında 173 Müslüman tarafından 212.478 kuruş kıymetinde 707 dönüm tarla ve 110 dönüm çayır arazi ile 133.475 kuruş kıymetinde 2 
hân, 21 hane, 1 değirmen, 5 dükkân ve 8 adet farklı türde emlâk satın alınmıştı. Gayr-i Müslim 10 kişi tarafından ise 6.700 kuruş kıymetinde 10 dönüm tarla arazisi ile 1.000 kuruş kıymetinde 1 hane satın alınmıştı. Müslüman 36 kişiye 82.700 kuruş kıymetinde 403 dönüm tarla ile 61 dönüm çayır arazide hak kararı ve 24.500 kuruş kıymetinde 2 hân 1 hane emlakta hak tasarrufu; gayr-i Müslim 3 kişiye de 3.000 kuruş kıymetinde 2,23 dönüm tarla arazisinde hak kararı ve 125 kuruş kıymetinde 1 bina arsasında hak tasarrufunun kesinlik kazanmasıyla bu kişilere tapu senedi verilmişti. İstatistikten kazada yoğun bir mülk alış-verişi olduğu anlaşılmakla birlikte, gerek satılan gerekse hak kararı verilen mülklerin toplu halde verilmesinden dolayı mülklerin ortalama değerleri konusunda bir değerlendirme yapmak mümkün olamamaktadır. İstatistikte ayrıca kaza dâhilinde 949.276 dönümü ekili ve 521.274 dönümü ekili olmayan olmak üzere toplam 1.470 .550 dönüm arazi olduğunun tapu kayıtlarından anlaşıldığı fakat bunun tam olarak gerçeği yansıtmadığı ifade edilmektedir (Y.EE., 133/1).

\section{Nafıa (Bayındırlık)}

Kazalarda bayındırlık işi kazanın tamamını ilgilendirdiğinden komisyon kaymakamın reisliğinde neredeyse kazadaki tüm kurumlardan gelen temsilcilerden oluşmaktaydı. Kazalardaki bayındırlık işlerine Nafia Komisyonu bakmaktaydı. Komisyon kazanın tüm bayındırlık işleriyle ilgilenmekle birlikte sorumlu oldukları işlerin başında yol yapımı gelmekteydi. Belediyelerin teşekkülüyle kaza dâhilindeki yol yapım ve tamir çalışmaları buraya bırakılmıştı (Yolalıcı 2002: 741-742). Ancak şehirlerarasındaki yollar yine nafia tarafından gerçekleştirilmekteydi. Bu kurum tarafından 1314 yılında yeni yol yapılmazken, 8.700 metre şose tamiri gerçekleştirildi.

Osmanlı Devleti’nde 19. yüzyılda küçük tarım üreticisi, çeşitli nedenlerden dolayı karşılaştığı ekonomik sıkıntıları aşmak için bazen borçlanmak zorunda kalmaktaydı. Ancak ilk başlarda resmi kredi sistemi olmadığından çiftçiler ya tefecilere başvurmak zorunda kalınıyor ya da selem usulüyle ürünü tarlada iken düşük fiyata satarak nakit ihtiyacını karşılamaya çalışıyordu. Çiftçi kredisini zamanında ödeyemediği zaman ise topraklarını kaybedebiliyordu. Mithat Paşa tarafından çiftçilerin bu sıkıntılarını gidermek amacıyla 1863 yılında Memleket Sandıkları adıyla kredi kurumları oluşturulmuştu. Memleket Sandıkları önce Menâfi Sandıklarına, daha sonra da Ziraat Sandıklarına dönüştürüldü. Bu sandık 25 yıllık faaliyetin ardından 1888'de bugünkü Ziraat Bankası adını aldı (Tabakoğlu 2002: 232).

Bayburt Ziraat Bank Şubesi’nin 1314 senesi başında mevcut sermayesi 2.097.354 kuruştu. Banka tarafından 1313 senesi sonuna kadar 965.268 ve 1314 senesi zarfında 95 
kişiye 116.225 kuruş borç verilmişti. Bahsedilen yılda verilen borçtan yapılan toplam tahsilat ise 42.705 kuruş olarak gerçekleşmişti. Böylece bankanın toplam 1.038.788 kuruş alacağı kalmıştı. ${ }^{8}$ Banka, Reis Abdurrahman Efendi, Muhasebe Kâtip Vekili Kadri Efendi, refik Abdülhadi Efendi ile azalar Şükrü Efendi, Hüseyin Efendi ve İpek Ağa tarafindan idare olunmaktaydı (SVE R.1315: 186).

Nafıaya ait sermayenin diğer hesapları ise şöyleydi: Yeni verilen borçlar 913.213, eskiden verilmiş borçlar 111.674, önceki senelere ait vergiler (hisse-i menâfi) 676.450, bu seneki vergiler 82.206, maliye hazinesine (hazîne-i celîle) verilen borç 263.584 ve taşınmaz mallar, demirbaş eşyalar ile mahkeme masrafı 146.646 kuruştu. Böylece sermaye toplam 2.193.773 kuruşa ulaşmaktaydı. Ayrıca aşardan alınan 62.968 kuruşluk eğitim vergisi (hisse-i ma'ârif) ve diğer sandıklardan verilen 125.687 kuruş bu hesabın dışındaydı (Y.EE., 133/1).

\section{Maarif (Eğitim)}

Kazanın eğitim işleri Maarif Komisyonu tarafından yürütülmekteydi. Komisyona reis olarak Kaymakam başkanlık ederken, azalar Belediye Reisi İsmail Hakkı Efendi, Rüştiye Muallim-i Evveli Osman Zeki Efendi, Maşuk Bey ve Edhem Efendi'den oluşmaktaydı (SVE R.1315: 186).

Kaza merkezinde 1314 senesi zarfinda mevcut mekâtib-i ibtidâiyeye ilaveten biri erkek (zükûr) diğeri kadınlara (inâs) ait olmak üzere iki adet yeni mekteb-i ibtidâiye açılmıştı. Böylece kazada erkekler için mekâtib-i ibtidâiye sayısı 14'e ulaşırken kadınlara ait ilk mekâtib-i ibtidâiye tesis edilmiş oldu. Yeni açılan bu okulların Öğretmen ve hademe maaşlarıyla masrafları maarif komisyon şubesince taahhüt edilmişti. Erkeklere ait mekteb-i ibtidâiye binası hükûmetin gözetimi altında yerel halka inşa ettirildi. Ayrıca mekâtib-i ibtidâiye dışında usûl-1 cedîdeye ${ }^{9}$ uygun eğitim yapmak üzere köylerde de iki adet mektep kuruldu. Kızlara ait mekteb-i ibtidâiye için de sonraki yıl yeni bir binanın

\footnotetext{
${ }^{8}$ Raporun üst kısmında bankanın toplam alacağ 1.038 .900 kuruş olarak verilmişse de yapılan hesaplamada 1.038.788 olduğu anlaşılmıştır. BOA, Y.EE., 133/1

9 İlköğretimde meydana gelen en önemli gelişmeden biri 18 Haziran 1869 tarihinde çıkarılan Maarif-i Umumiye Nizamnamesi ile gerçekleşmişti. Bu tarihten itibaren ders araç ve gereçleri konusundaki yenileşme, özellikle öğretmenlerin geleneksel öğretim yöntemlerini bırakıp yeni ve etkili öğretim yöntemlerini uygulamasına usûl-i cedîd hareketi denildi. Yeni tarzda eğitim veren okullara usûl-i cedîd mektebi veya mekteb-i iptidai denilirken yeniliklerin uygulanmadığ 1 okullara da Sibyan Mektebi denilmekteydi. Ayrıca mekteb-i iptidai okulları Maârif Nezâreti'ne bağlanmışken, sıbyan mektepleri Evkaf Nezâreti'ne bağlı olarak eski durumlarını sürdürmüşlerdi. Yahya Akyüz, Türk Eğitim Tarihi, Ankara: Pegem Akademi, 2013, s.209; Yücel Gelişli, "Osmanlı İlköğretim Kurumlarından Sıbyan Mektepleri (Kuruluşu, Gelişimi ve Dönüşümü)”, Türkler, c.15, Ankara: Yeni Türkiye Yayınları, 2002, s. $40-42$
} 
inşası gerçekleşti (Y.EE., 133/1). Bu tarihteki okullar hakkında gerek vilayet salnamesinde gerekse maarif salnamesinde 2'i merkezde 3'ü köylerde olmak üzere 5 mekâtib-i ibtidâiye hakkında bilgi verilmektedir. Bu bilgilere göre öğrenci sayısı 161 olan Merkez Mekteb-i İbtidâiyenin Muallim-i Evveli: Hafız Hüseyin Ramizi Efendi, Muallimi Sânî: Ali Efendi ve Muallim-i Sâlis: Hüseyin Efendi olmak üzere üç hocası bulunmaktaydı. Zâhid mahallesinde bulunan ve öğrenci sayısı 49 olan mekteb-i ibtidâiyede ise muallimlik görevini Mehmed Efendi yürütmekteydi. Açılmasına karar verilen İnas Mekteb-i İbtidâiyenin bir sonraki yıl öğrenci sayısı 31 iken muallimeliğini Münire Hanım yürütmekte ve bevvaplığını da Şerif Ağa yapmaktaydı. ${ }^{10}$

Nahiye merkezlerinde 1313 senesinde açılan mekâtib-i ibtidâiye binalarının inşası için yapılan düzenleme, vilayet makamına tasdik ettirilmiş ve yapılan plan çerçevesinde yalnız Pulur Nahiyesi merkezindekinin inşasına başlanmıştı. İnşaatın bitirilmesine yaklaşılmışken kış mevsiminin gelmesinden dolayı kalan eksiklikler 1314 yılında tamamlanabildi. Diğer iki nahiye merkezinde ise yardım yoluyla mevsiminde inşaata başlanmak üzere tespit edilen masraflar için tahsilat yapılmaktaydı (Y.EE., 133/1). Bu okullar salnamelerde Hamidiye Mekteb-i İbtidâiye adıyla yer almaktadır. Okulların üçünde de çocukları getirip götürmekle sorumlu olan bevvap (hademe) kadrosu boştu. Muallim ve öğrenci sayılarına bakıldığında Pulur Nahiyesinde muallim Salih Efendi, öğrenci sayısı 57, Hart Nahiyesinde muallim Hafiz Receb Efendi, öğrenci sayısı 60 ve Everek Nahiyesinde muallim Ahmet Efendi, öğrenci sayısı ise 41'di (SVE R.1315: 187188).

Bayburd Mekteb-i Rüşdiyesinde 1313 senesinde 76 öğrenci mevcuttu. Yeni açılan mekteb-i ibtidâiye ve mevcut okulların sslahı neticesinde 1314 eğitim-öğretim yılının başında öğrenci mevcudu 130'a ulaşmıştı. Öğrenci sayısındaki artış neticesinde bir muallime daha ihtiyaç duyulduğu vilayet kaymakamına arz olunmuştu. $\mathrm{Bu}$ atama yapılıncaya kadar ise ihtiyaç duyulan muallimin maaşı maarif komisyon şubesince taahhüt edilerek eğitime devam edilmekteydi (Y.EE., 133/1). İstatistikte öğrenci sayıs1 130 olarak verilmekle birlikte salnamelerde 138 öğrencisi bulunan bu okulda dört öğretmen görev yapmaktaydı. Bunlar: Muallim-i Evvelî: Osman Zeki Efendi, Muallim-i Sânî: Abdullah Ramiz Efendi, Muallim-i Sâlis: Hafız Şükrü Efendi ve Hat Muallimi ise

\footnotetext{
${ }^{10}$ Maarif salnamesinde öğrenci sayısı Merkez Mekteb-i İbtidâiyyesi için 143, Zahid Mekteb-i İbtidâiyyesi için ise 50 olarak verilmektedir. Bakınız: Özger, XIX. Yüzyıl Bayburt, s.404-406; Salnâme-i Vilâyet-i Erzurum, Defa 14, s.187; Salnâme-i Vilâyet-i Erzurum, Defa 15, Rumi 1316 (14 Mart 1900/13 Mart 1901), s.291
} 
meşhur şair Bayburdlu Zihni'nin oğlu Ahmed Revâni Efendi’ydi (SVE R.1315: 186; Özger 2008: 408).

\section{Belediye Dairesi}

Belediye dairesinde 1314 yılında Reis İsmail Hakkı Efendi tarafından idare olunmakta ve aza olarak da Abdurrahman Efendi, Mahmud Ağa, İpek Ağa ve Arakil Efendi görev yapmaktaydı. Bu kişiler dışında belediyede Tabip Vekili: Yüzbaşı Asaf Efendi, Belediye Kâtibi: Alişan Bey, Sandık Emini: Umur Efendi, İcracı: Panko Efendi ve iki çavuş istihdam edilmekteydi (SVE R.1315: 187).

Belediye Dairesi tarafından 1314 senesi zarfında 700 arşınlık (530,6 metre $)^{11}$ yeni şose inşası ve 300 arşınlık (227,4 metre) lağım tamiri gerçekleşmiş ve 23 bina inşası için de ruhsat verilmişti.

Belediyenin o yılki gelirleri 58.302 kuruş olarak gerçekleşirken, 41.605 kuruş masraf yapılmıştı. Dolayısıyla belediye gelir-gider dengesinde 16.697 kuruş fazla verilmişti. Belediyenin 1315 senesine devreden sermayesi, mevcut sandik ile gelirler ve alacaklardan kalan 294.379 kuruştan ibaretti.

Mehmed Hüsnü Bey, istatistikteki bütün bu tutar ve gelirlere karş1l1k gösterilerek lüzumu hissedilen bir ıslahhane inşasını vilayet makamına arz etmiş ve bunun için müsaade istenmişse de aradan geçen bir buçuk seneye rağmen bu konuda henüz bir cevap alınamamıştı. Kira ile tedarik edilmiş olan hükûmet dairesinin mevcut durumu hükümetin şanına uygun görülmemekteydi. Bundan ötürü toplum idaresi için mevcut yardımlar yeterli ve gerekli şartları taşıyan diğer binalar da olmadığından yeni bir hükümet dairesinin inşa olunması gereği de vilayet makamına arz edilmişti. Mehmed Hüsnü Bey'in bu talebi Erzurum vilayeti tarafından kabul edilerek inşaat mevsiminin başında 1315 senesi gelirlerinden yeni bir hükümet binasının inşası için bütçeye yeterli miktar tahsis edilmiş ve inşaatına başlanmıştı (Y.EE., 133/1; Özger 2008: 65).

İstatistikte adli konular ile ilgili sadece 1314 yılı içinde kazada 31 cinayet ile 155 suç olayının yaşandığı ifade edilmiştir. Bir yıl içerisinde gerçekleşen bu kadar cinayet ve suç vakası, aslında yaklaşık 57 bin nüfuslu bir bölge için ciddi bir rakamdı ve bölgede asayiş konusunda ciddi sorunların olduğuna işaret etmekteydi. Belgede bu konuda ayrıntı verilmemekle birlikte istatistiğin yazılmasından kısa bir süre önce 1895 yılında Bayburt

\footnotetext{
${ }^{11}$ Metrenin resmen kabulüne kadar Osmanlı'da iki türlü arşın kullanılmaktaydı. Bunlardan biri çarşı arşını diğeri ise mimar arşını idi. Mimar arşını metrenin binde 758'ine karşılık gelmekte olup $1 \mathrm{~m}=75,8 \mathrm{~cm}$ 'ydi. Bakını: Mehmet Zeki Pakalın, Osmanlı Tarih Deyimleri ve Terimleri Sözlüğ̈̈-I, İstanbul: MEB Yayınları, 2004, s.88
} 
ve çevresinde Ermeni olayları patlak vermişti. ${ }^{12}$ Dolayısıyla yukarıdaki cinayet ve suç olaylarının bu hadiseler ile bağlantılı olduğu düşünülmektedir.

Belgenin sonunda Mehmed Hüsnü Bey, verilen istatistikten bazı dairelerin esaslı bir şekilde sslaha muhtaç olduğunu ve yapılması istenen dairelerin onaylanması durumunda imkânlar çerçevesinde gerekli tedbirlerin alınmakta olunduğu, istatistikte bazı eksiklerin bulunduğu ve bu dönemde halkın refahının arttığı vurgulanmakla birlikte artan devlet gelirleri ile gerekli tadilatların yapılmasının umulduğunu ifade etmektedir.

\section{Sonuç}

Kaymakam Mehmed Hüsnü Bey’in hazırlamış olduğu istatistik göstermektedir ki bölgedeki yöneticiler ve halk Bayburt Kazasının kalkınması için imkânları çerçevesinde yoğun emek harcamışlardır. Özellikle idari ve eğitim alanında ihtiyaç duyulan yeni kurumlar için gerekli bina ve elemanların tesis ve temini konusunda yardımsever vatandaşlardan toplanan yardımlar ile bu eksiklikler bir nebze giderilmeye çalışılmıştır. Fakat modern eğitim kurumlarının oluşturulması amacıyla 1869 yılında yayınlanan Maarif Nizamnamesinden yaklaşı 30 yıl geçmesine rağmen hala bina ve öğretmen sıkıntısının yaşanması bu gayretlerin yetersizliğini ortaya koymaktadır. İstatistikte, kazanın son yıllardaki vergi gelirlerinin arttığı anlaşılsa da bölgenin en önemli ekonomik faaliyeti olan tarım ve hayvancılık alanında, son dönemlerde bölgede meydana gelen olumsuzlukların da etkisiyle, gerileme yaşandığı ve bu konuda modern tarıma geçilmesi için çabalar sarf edildiği açık bir şekilde dile getirilmiştir. Aslında kazanın ihtiyaçlarının giderilmesi, o dönemin şartlarında pekte kolay değildi. Çünkü o dönemde Osmanlı Devleti'nin içinde bulunduğu siyasi ve ekonomik durum ve bölge üzerinde özellikle Ermeni halkı üzerinden yapılan dış baskıların mevcudiyeti, bu alanlara yeterince el atılmasını imkânsız kılmaktaydı. Bu durumun doğal sonucu olarak da kazadaki kalkınma, idareci ve halkın ileri gelenlerinin çabalarıyla sınırlı kalmıştır.

\section{Kaynakça}

\section{Arşiv Belgeleri}

A.MKT.MHM. (Sadaret, Mühimme Kalemi Evrak1 Fonu), 680/29, H. 20 Şaban 1314 [24 Ocak 1897].

BEO (Bab-1 Ali Evrak Odası Fonu), 1346/100917, H. 19 Rebiyülevvel 1317 [28 Temmuz 1899].

\footnotetext{
${ }^{12}$ Bu konuda detaylı bilgi için bakınız: Yunus Özger, 1895 Bayburt Ermeni Ayaklanmaları.
} 
MF.MKT. (Maarif Nezareti, Mektubi Kalemi Fonu), 421/15, 16 Cemaziyülahır 1316 [1 Kasim 1898].

Y.EE. (Y1ldı Esas Evrak Fonu), 133/1, , H. 29 Zilkade 1316 [10 Nisan 1899].

\section{Salnameler}

Salnâme-i Vilâyet-i Erzurum (SVE) (Rumi 1313). Defa 13, Erzurum: Erzurum Vilayet Matbaas1.

Salnâme-i Vilâyet-i Erzurum (SVE) (Rumi 1315). Defa 14, Erzurum: Erzurum Vilayet Matbaasi.

Salnâme-i Vilâyet-i Erzurum (SVE) (Rumi 1316). Defa 15, Erzurum: Erzurum Vilayet Matbaasi.

\section{Araștırma Eserler}

AKYÜZ, Yahya (2013). Türk Eğitim Tarihi, Ankara: Pegem Akademi.

ÇADIRCI, Musa (1997). Tanzimat Döneminde Anadolu Kentleri’nin Sosyal ve Ekonomik Yapısı, Ankara: TTK.

BULUT, Çağdaş Engin (2015). “Devletin Taşradaki Eli: Umumi Müfettişlikler”, CTAD, 11(21): 83-110.

DEMIREL, Ömer GÜRBÜZ, Adnan ve TUŞ, Muhittin (1992). "Osmanlılarda Ailenin Demografik Yapısı", Sosyo-Kültürel Değişme Sürecinde Türk Ailesi, Cilt 1, ss. 97-161, Ankara: Başbakanlık Aile Araştırma Kurumu.

Evliya Çelebi (H.1314). Evliya Çelebi Seyahatnamesi, İstanbul: İkdam Matbaas1.

GELİŞLİ, Yücel (2002). "Osmanlı İlköğretim Kurumlarından Sıbyan Mektepleri (Kuruluşu, Gelişimi ve Dönüşümü)", Türkler, Cilt 15, ss. 35-43, Ankara: Yeni Türkiye Yayınları.

GENÇ YILMAZ, Ayfer (2013). "Devlet Kapasitesi ve Umumi Müfettişlikler Altyapısal İktidarın Yerelde İnşası”, Siyasal Bilimler Dergisi, 1(1): 43-65.

HINZ, Walther (1990). İslâm'da Ölçü Sistemleri, (Çev. Acar Sevim), İstanbul: Edebiyat Fakültesi Basımevi.

KALLEK, Cengiz (24.01.2019). "Kile", TDV İslâm Ansiklopedisi, https://islamansiklopedisi. org.tr/kile. 
KOÇAK, Cemil (2010), Umumi Müfettişlikler, İstanbul: İletişim Yayınları.

MİROĞLU, İsmet. (23.01.2019). "Bayburt", TDV İslâm Ansiklopedisi, https://islamansiklopedisi. org.tr/bayburt.

ORTAYLI, İlber (2011). Tanzimat Devrinde Osmanlı Mahalle İdareleri (18401880), Ankara: TTK.

ÖZGER, Yunus (2007). 1895 Bayburt Ermeni Ayaklanmaları, İstanbul: IQ Kültür Sanat Yayıncılık.

ÖZGER, Yunus (2008). XIX. Yüzyll Bayburt (Sosyo-Ekonomik, Idari ve Demografik Yapı), İstanbul: IQ Kültür Sanat Yayıncılık.

PAKALIN, Mehmed Zeki (2004). Osmanlı Tarih Deyimleri ve Terimleri Sözlüğü-I, İstanbul: MEB Yayınları.

PAKALIN, Mehmed Zeki (2004). Osmanll Tarih Deyimleri ve Terimleri Sözlüğ̈̈-II, İstanbul: MEB Yayınları.

SEYITDANLIOĞLU, Mehmet (2010). Tanzimat Döneminde Modern Belediyeciliğin Doğuşu, İstanbul: Türkiye İş Bankası Kültür Yayınları.

SOMEL, Selçuk Akşin (1995). “Osman Nuri Paşa'nın 17 Temmuz 1885 Tarihli Hicaz Raporu” A.Ü., D.T.C.F., Tarih Araştırmaları Dergisi, 18(29): 43-65.

TABAKOĞLU, Ahmet (2003). Türk İktisat Tarihi, İstanbul: Dergâh Yayınları.

TABAKOĞLU, Ahmet (2002). "Yenileşme Dönemi Osmanlı Ekonomisi". Türkler, Cilt 14, ss. 207-240, Ankara: Yeni Türkiye Yayınları.

YOLALICI, Mehmet Emin (2002). Osmanlılarda Çağdaş Belediyecilik. Türkler, Cilt 13, ss. 739-749, Ankara: Yeni Türkiye Yayınları. 
Yıldıray YILDIRIM, “Kaymakam Mehmed Hüsnü Bey’in Raporuna Göre 19. Yüzyıl Sonunda Bayburt Kazasının Genel Durumu”, Mavi Atlas, 7(2)/2019: 121-140

\section{Ekler:}

\section{Ek 1. Bayburd kazâsının üç yüz on dört senesine 'â'id mu âmelât-ı idârîye istâtistîkîdir.}

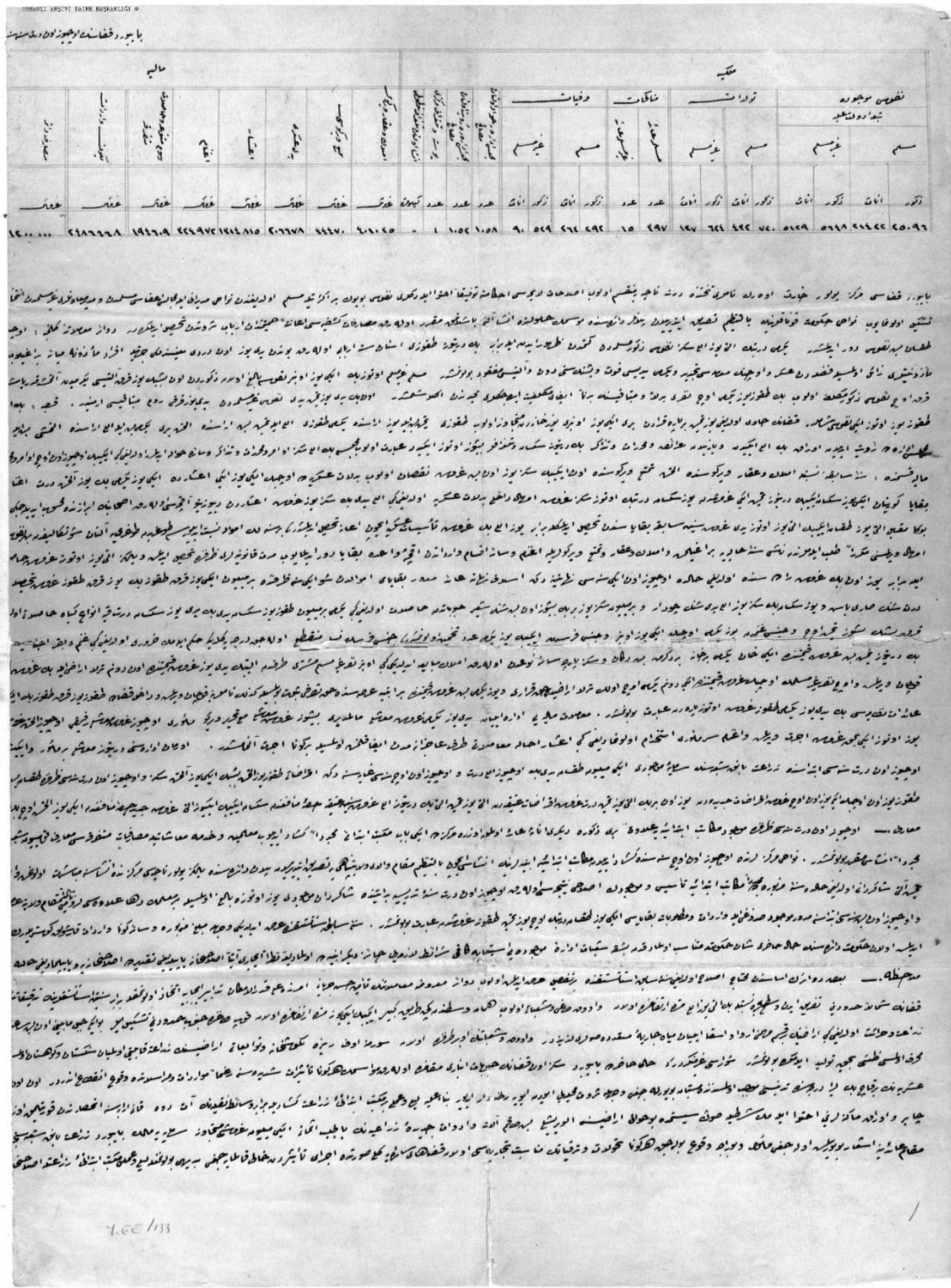

Y.EE.00133 
Yıldıray YILDIRIM, “Kaymakam Mehmed Hüsnü Bey’in Raporuna Göre 19. Yüzyıl Sonunda Bayburt Kazasının Genel Durumu”, Mavi Atlas, 7(2)/2019: 121-140

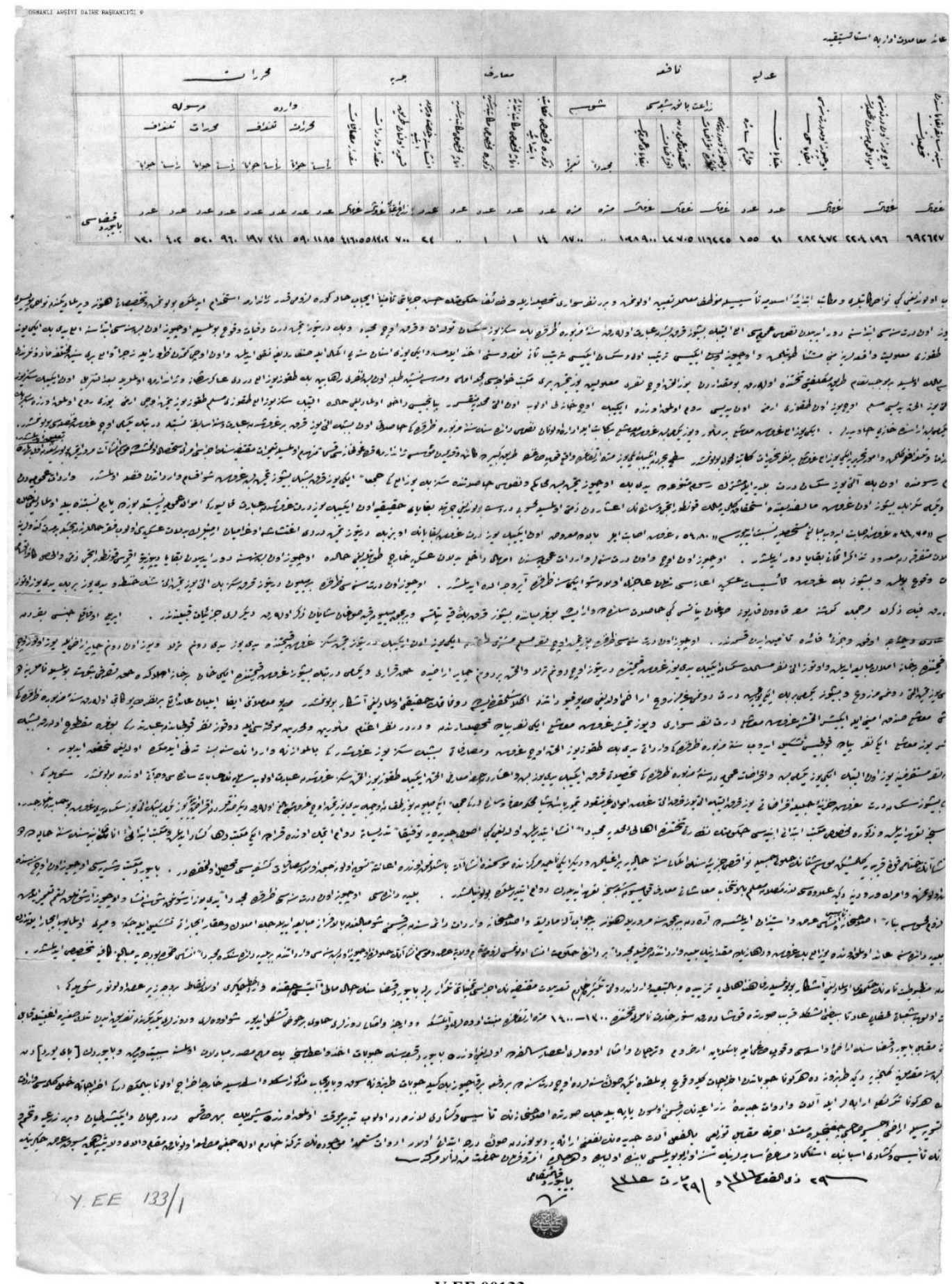

Y.EE.00133

Y.EE. (Yıld1z Esas Evrak Fonu), 133/1, , H. 29 Zilkade 1316 [10 Nisan 1899]. 